\title{
Compensation and Work Discipline on Teachers' Performance: A Multifactorial Design
}

\author{
Sihabudin', \\ DOI: $10.35445 /$ alishlah.v13i3.1443
}

\begin{abstract}
Article Info
Abstract

Keywords:

Compensation;

Work discipline;

HRM Education;

Teachers' performance;

The purpose of this study is to measure the links between compensation and work disciplines towards the teachers' performance. Underlying the concept of Human Resources Management (HRM) education, this study investigates the effect of the two aforementioned variables on the teacher's pedagogical approach, classroom activities, and teaching strategies using technology. This research was conducted using a quantitative approach, specifically a multifactorial design. The sample of this current study was 53 people. The data was gathered through administering questionnaires. The data analysis used was a descriptive statistics and multiple linear regression analysis. The results showed that simultaneously the compensation and work discipline variables had a positive and significant effect on the teachers' performance, and partially compensation and work discipline had a positive and significant effect on the teachers' performance. The multiple linear regression equation is $\mathrm{Y}=20.789+0.299 \mathrm{X} 1+0.271 \mathrm{X} 2$. Meanwhile, the results of the descriptive analysis show that the variables of compensation, work discipline, and teachers' performance are in a good criteria.
\end{abstract}

Kata kunci:

Pendidikan;

Pendidikan Sumberdaya

Manusia;

Pendidikan kedisiplinan;

Kinerja Guru;

\begin{abstract}
Abstrak
Tujuan dari penelitian ini adalah untuk mengukur hubungan antara kompensasi dan disiplin kerja terhadap kinerja guru. Mendasari konsep pendidikan Manajemen Sumber Daya Manusia (SDM), penelitian ini menyelidiki pengaruh dua variabel tersebut pada pendekatan pedagogis guru, aktivitas kelas, dan strategi pengajaran menggunakan teknologi. Penelitian ini dilakukan dengan menggunakan pendekatan kuantitatif, khususnya desain multifaktorial. Sampel penelitian ini adalah 53 orang. Pengumpulan data dilakukan melalui tes dan angket. Analisis data yang digunakan adalah statistik deskriptif dan analisis regresi linier berganda. Hasil penelitian menunjukkan bahwa secara simultan variabel kompensasi dan disiplin kerja berpengaruh positif dan signifikan terhadap kinerja guru, dan secara parsial kompensasi dan disiplin kerja berpengaruh positif dan signifikan terhadap kinerja guru. Persamaan regresi linier berganda adalah $\mathrm{Y}=20.789+0.299 \mathrm{X} 1+0.271 \mathrm{X} 2$. Sedangkan hasil analisis deskriptif menunjukkan bahwa variabel kompensasi, disiplin kerja, dan kinerja guru berada pada kriteria baik.
\end{abstract}

\footnotetext{
${ }^{1}$ Universitas Buana Perjuangan Karawang, Karawang, Indonesia Email: sihabudin@ubpkarawang.ac.id
} 


\section{INTRODUCTION}

Education is believed to be one of the fields that has an important and strategic role in developing a nation. It has even become a dominant factor in increasing the nation's intelligence and economic growth (Gopinatham, 2013; Ozturk, 2001). The importance and strategic role of education in nationbuilding has been recognized since the formulation of UUD in 1945. Without intelligence, a nation can not participate in the global arena. Given the important and strategic role of the education sector, the development of human resources in this field is a demand, both formal juridical demands, operational technicalities, and demands for theoretical mastery and empirical practice. The question is how to develop human resources oriented towards improving the quality and achievement of national education goals.

As a response to the question, an organization must manage human resources effectively in order to achieve optimal performance. A critical factor in an organization's success is the presence of capable and skilled human resources with positive morale. It is expected to achieve maximum performance in order to assist the organization in accomplishing its objectives. Every organization expects the best and most efficient performance from its employees because with the best and most efficient performance, the organization can achieve its maximum goals (Sihabudin, 2017). Performance is the outcome of a group of people or an individual's work within an agency according to their respective authorities and responsibilities to accomplish organizational goals. Numerous factors can have an effect on a person's performance. According to Kashmir (2016), performance is influenced by abilities and expertise, knowledge, work design, personality, work motivation, leadership, leadership style, organizational culture, job satisfaction, work environment, loyalty, commitment, and work discipline. Teachers' motivation can be increased by compensating them for their contributions to the organization.

Compensation includes all direct and indirect payments in the form of benefits and incentives designed to motivate teachers to work more efficiently. The agency compensates teachers who work efficiently and contribute to the organization's success. Compensation can significantly impact teacher performance; if the agency or organization fulfills its obligation, namely compensating each teacher, this can serve as a motivator for teachers to work even harder and achieve the organization's expected performance (Liu, 2012). Thus, it is critical to recognize teachers who have achieved success by compensating or incentivizing them.

Teachers' performance can also be affected by their work environment. The ability to work regularly, diligently, continuously, and in accordance with applicable rules is referred to as "work discipline." The quality of a teacher's work is directly correlated to the quality of their work-life discipline (Farisi \& Fani, 2019; Fudiyah \& Harapan, 2021). The teacher's performance will improve if the teacher's work ethic is high, and vice versa. The BKPSDM Karawang Regency must also pay attention to the importance of compensation and work discipline to improve each teacher's performance. BKPSDM is a government agency responsible for staffing in the Karawang district government. Legislation No. 5 of 2014 pertaining to the State Civil Apparatus, including rules governing the Personnel Agency (BKPSDM). As an administrative body, the district government of Karawang employs the BKPSDM, which is tasked with developing and implementing the district's policies and procedures for teacher management (Sihabudin, 2018b).

There are still teachers who believe that their pay is in line with expectations, as evidenced by preresearch on compensation; as a result, no one's pay is in line with the average teacher's expectations. Although some teachers still believe the benefits they receive are adequate, this indicates that teachers believe the benefits they receive are not in line with expectations (Sihabudin, 2019b). Furthermore, the presence of teachers who believe that the work environment does not meet their needs should not exist and should be evaluated immediately in order to ensure that each job runs as smoothly and efficiently as possible. Teachers may be inspired to work harder because of the agency's generous compensation. According to (Panjaitan, 2020), compensation can affect teacher performance. This shows that teachers' performance can be affected by compensation. There have also been a number of studies on 
the subject of workplace rules. To give one example, according to the findings of Fadli et al. (2017), teachers' ability to perform better has been shown to be positively impacted by a strong sense of work ethic. Another study, conducted by Sungkono (2016), found that teachers' performance is affected by their work discipline. Finally, there is the research done by Wanta (2017), which states that teachers' performance is significantly influenced by their work discipline. As a result, each teacher's performance can be affected by their work ethic.

According to Rivai and Basri (Masram, 2017), when evaluating a person's performance over a period of time, consider how well they've done compared to a set of predetermined criteria, such as work standards, goals, or predetermined targets. As Robbins in Bintoro (2017) asserts, five indicators can be used to measure individual teachers' performance. In order to determine the quality of a teacher's work, the teacher looks at the quality of the work they have produced and the level of perfection they have achieved in the task. (2) Amount; When we talk about the quantity of work, we're talking about how many units and activity cycles were completed. With regard to maximizing the amount of time that can be used for other activities, punctuality refers to how much work is done before the stated deadline. With the goal of maximizing each unit's results in the use of resources, effectiveness refers to the level of utilization of organizational resources (manpower, money, technology, and raw materials). As a teacher, you need to be able to carry out your responsibilities even if you have other commitments. Teacher commitment to the agency, and the teacher's responsibilities as a member of the workforce at the company where he works, are at this level (Sihabudin, 2019a).

Regarding work discipline, Rivai (2014) states that it is a tool used by managers to communicate with teachers to elicit their willingness to change a behavior and an effort to increase one's awareness and willingness to follow all applicable company regulations and social norms. According to Singodimedjo in Sutrisno (2016), work discipline consists of four components: 1. Adhering to the rules of time; 2. Adhering to the rules of the company; 3. Adhering to the rules of behavior; and 4. Adhering to other rules. Yani (2012) defines compensation as a form of payment, either directly or indirectly, that benefits teachers by motivating them to improve their work productivity. Additionally, it mentions five indicators, including (1) Salary; Salary is a monthly stipend paid to teachers in exchange for their contributions. (2) Wages; Wages are compensation paid directly to teachers based on the number of hours worked. (3) Incentives; Incentives are monetary rewards paid directly to teachers whose performance meets or exceeds specified standards. Allowances are remuneration paid to certain teachers in exchange for their sacrifices. (5) Facilities; Facilities are administrative and support services an organization or business provides.

The factors that have been discussed have a significant impact on the effectiveness of the teachers. As a result, scientists are scrambling to establish a link between their findings. The researchers conduct this study in order to examine this correlation. Teachers should be inspired to do better by this study. More importantly, stakeholders are urged to recognize and reward teachers who go above and beyond the call of duty, encouraging them to put in extra effort to improve their own performance. Last but not least, this study serves as a useful resource for scholars and researchers interested in examining issues of compensation, work discipline, and teachers' performance in the context of school districts.

\section{METHODS}

This research was a descriptive survey using an ex-post-facto design that included determining and describing the influence affecting teachers' performance as a result of compensation and work discipline. The target of this study was 53 teachers of Karawang city who were willing to be participants of this study. Their willingness was proven by filling the consent forms before they were asked to fill in the questionnaires. The data was collected through administering questionnaires. The instruments were developed from the theory of teachers' performance in relation to the compensation and work disciplines as a part of Human Resources Management education. To analyse the obtained data, Pearson t-test and ANOVA were utilized. The hypotheses were tested using product-moment 
correlation and basic regression analysis. All hypotheses were tested at a significance threshold of 0.05 or a 95 percent certainty of prediction.

\section{FINDINGS AND DISCUSSION}

The results show that the effect of compensation and work discipline on the teachers' performance obtains a significant value of $0.003<0.05$. Moreover, the effect of compensation on the teachers' performance also shows a significant value of $0.021<0.05$, as well as the effect of work discipline on the teachers' performance which showcases another significant value of $0.026 .<0.05$.

Table 1. Multiple Linear Regression Analysis Results

\begin{tabular}{ccccccc}
\hline \hline \multirow{2}{*}{ Model } & \multicolumn{2}{c}{$\begin{array}{c}\text { Unstandardized } \\
\text { Coefficients }\end{array}$} & & $\begin{array}{c}\text { Standardized } \\
\text { Coefficients }\end{array}$ & $\mathrm{t}$ & Sig \\
\cline { 3 - 6 } & $\mathrm{B}$ & $\begin{array}{c}\text { Std } \\
\text { Error }\end{array}$ & Betta & & \\
\hline 1 & (Constant) & 20.789 & 7.395 & & 2.811 & .007 \\
& Compensation & .299 & .125 & .305 & 2.388 & .021 \\
& Dicipline & .274 & .120 & .292 & 2.287 & .026
\end{tabular}

a. Dependent Variable: Performance

Based on the results of the analysis (table 1), it is obtained that the multiple linear regression equation is $\mathrm{Y}=20,789+0,299 \mathrm{X} 1+0,271 \mathrm{X} 2+\varepsilon$.

Table 2. Coefficient of Determination

\begin{tabular}{lrrrr}
\hline & & & \\
Model & $\mathrm{R}$ & R Square & Adjusted R Square & $\begin{array}{c}\text { Std. Error of the } \\
\text { Estimate }\end{array}$ \\
\hline 1 & & $.461^{\mathrm{a}}$ & .181 & \\
a. Predictors: (Constant), Dicipline, Compensation & \\
\hline \hline
\end{tabular}

Table 2 shows that the value of the coefficient of determination or R Square (R2) is 0.212 or $21.2 \%$. This shows that compensation and work discipline together can affect Teacher performance by $21.2 \%$, while the remaining $78.8 \%$ is influenced by other variables not examined.

\section{Hypothesis Test}

To partially test the hypothesis between the independent variable (X) and the dependent variable $(\mathrm{Y})$, the $\mathrm{t}$ statistic test is used, the t-test is used to determine whether the independent variable partially affects the dependent variable. If tcount $>t_{\text {table }}$ then the result has a significant effect and means that $\mathrm{H}_{\mathrm{o}}$ is rejected and $\mathrm{H}_{\mathrm{a}}$ is accepted. Meanwhile, if tcount $<t_{\text {table }}$ then the result has no significant effect and means that $\mathrm{H}_{\mathrm{o}}$ is accepted and $\mathrm{H}_{\mathrm{a}}$ is rejected.

\section{Hypothesis I: Effect of Compensation on Teacher Performance}

Based on Table 1, compensation (X1) on Teacher performance (Y) is known to have a significant value of $0.021<0.05$ and a tcount value of $2.388>1.675$. So it can be interpreted that $\mathrm{H}_{\mathrm{o}}$ is rejected and $\mathrm{H}_{\mathrm{a}}$ is accepted, which means that compensation has a positive and significant effect on Teacher performance. Hypothesis I; The Effect of work discipline on the teachers' performance based on Table 
1.2 shows that work discipline (X2) on Teacher performance $(\mathrm{Y})$ is known to have a significant value of $0.026<0.05$ and the value of tcount is $2.287>1.675$. So that it can be interpreted that $\mathrm{H}_{\mathrm{o}}$ is rejected and $\mathrm{H}_{\mathrm{a}}$ is accepted, which means that work discipline has a positive and significant effect on the teachers' performance.

The $\mathrm{F}$ test is used to simultaneously determine the effect of all the $\mathrm{X}$ variables in the research model on the $\mathrm{Y}$ variable. If sig >, Ho is accepted and Ha is rejected, resulting in a non-significant effect; if sig, Ho is rejected and $\mathrm{Ha}$ is accepted, resulting in a significant effect.

Table 3. F test Result

\begin{tabular}{|c|c|c|c|c|c|c|}
\hline \multicolumn{7}{|c|}{ ANOVA } \\
\hline Model & & $\begin{array}{l}\text { Sum of } \\
\text { Squares }\end{array}$ & Df & Mean Square & $\mathrm{F}$ & Sig. \\
\hline \multirow[t]{3}{*}{1} & Regression & 525.677 & 2 & 262.839 & 6.730 & .003 \\
\hline & Residual & 1952.625 & 50 & 39.052 & & \\
\hline & Total & 2478.302 & 52 & & & \\
\hline
\end{tabular}

a. Predictors: (Constant), Dicipline, Compensation

b. Dependent Variable: Performance

Table 3 shows the results of the stealth testing of compensation and work discipline on Teacher performance, it is known that the significance value is $0.003<0.05$ and the Fcount value is $6.730>$ 3.18. So it can be interpreted that $\mathrm{H}_{\mathrm{o}}$ is rejected and $\mathrm{H}_{\mathrm{a}}$ is accepted, which means that compensation and work discipline have a positive and significant effect on Teacher performance. The research shows that there is an effect of compensation on Teacher performance, a significance value of $0.021<0.05$ and a tcount of $2.388>1.675$ ttable. This means that $\mathrm{H}_{\mathrm{o}}$ is rejected and $\mathrm{H}_{\mathrm{a}}$ is accepted, which means that compensation has a positive and significant effect on the teachers' performance (Sihabudin, 2018a). The results of this study are in line with research conducted by (Nurhanispa, 2020) whose research results state that compensation has a significant effect on the teachers' performance. Other research that is relevant to the results of this study is research conducted by Yulandri (2019) whose research results state that compensation has a significant effect on Teacher performance. The study showed that there was an effect of work discipline on the teachers' performance, a significance value of $0.026<0.05$ and a tcount of $2.287>1.675$ was obtained. This means that $\mathrm{H}_{\mathrm{o}}$ is rejected and $\mathrm{H}_{\mathrm{a}}$ is accepted, which means that work discipline has a positive and significant effect on the teachers' performance. The results of this study are in line with research conducted by Wanta (2017) whose research results report that work discipline has a significant effect on the teachers' performance. Other studies relevant to this study's results are research conducted by Sungkono (2016) who mentions that work discipline has a partial effect on performance.

The study showed that the effect of compensation and work discipline on the teachers' performance obtained a significant value of $0.003<0.05$ and an $\mathrm{F}_{\text {count }}$ of $6.730>3.18 \mathrm{~F}_{\text {table. This means }}$ that $\mathrm{H}_{\mathrm{o}}$ is rejected and $\mathrm{H}_{\mathrm{a}}$ is accepted, which means that compensation and work discipline together have a positive and significant effect on the teachers' performance. The results of this study are in line with research conducted by Nurhanispa (2020) who states that compensation and work discipline have a simultaneous and significant effect on the teachers' performance. In short, it can be said that the presumption considering that the compensation and work disciplines influence teachers' performance is scientifically proven. It is undeniably that to boost teachers to perform better, institutions have to improve appreciations in terms of payment and develop the quality of discipline. 


\section{CONCLUSION}

The important role of education in nation-building has clearly been demonstrated in formal juridical and operational empirical practice. The human resources needed in the field of education are qualified human resources in thinking and doing in order to create optimal performance of educators. Among the HRM practices, compensation and work discipline present as factors influencing teachers' performance. Based on the results and discussions described, it can be concluded that the compensation and work disciplines have positive and significant effects on the teachers' performance. As well as compensation, work discipline simultaneously has a positive and significant influence on the teachers' performance. This results imply that in order to motivate teachers to increase their performance, it is suggested that extra incentives are provided for those who gain achievement beyond the expectations. Moreover, the improvement of work disciplines is also another effort that must be considered to implement in the working environment. The researchers are aware that this study has many limitations. Therefore, further studies are encouraged to conduct as a way to complete the weaknesses. First weakness is invalidating the instruments for data collection. The researchers did not adhere any scientific measurements to decide the reliable instruments for collecting the data. Recognizing this current issue, the next writers have to conduct validity and reliability test to make sure that the instruments are trusted to utilize. Second weakness is in the discussion section. It is admitted that the discussion part is not completely comprehensive due to the writers' limitation. To fill this void, the further researchers are motivated to serve more detailed and broad discussions.

\section{REFERENCES}

Bintoro. (2017). Manajemen Penilaian Kinerja Karyawan. Gava Media.

Farisi, S., \& Fani, W. M. (2019, October). Influence of Work Environment and Work Discipline on Employee Performance. In International Conference on Global Education (pp. 69-81).

Fudiyah, U. N., \& Harapan, E. (2021, July). Work Discipline and Principal Leadership in Influencing Teachers' Performance. In International Conference on Education Universitas PGRI Palembang (INCoEPP 2021) (pp. 839-843). Atlantis Press.

Hasibuan. (2012). Manajemen Sumber Daya Manusia. Bumi Aksara.

Gopinathan, S. (2013). Education and the nation state: The selected works of S. Gopinathan. Routledge.

Ozturk, I. (2001). The role of education in economic development: a theoretical perspective

Kashmir. (2016). Manajemen Sumber Daya Manusia (Teori dan Praktik). PT Raja Grafindo Persada.

Liu, S. (2012). The influences of school climate and teacher compensation on teachers' turnover intention in China. Educational Psychology, 32(5), 553-569.

Masram, \& M. (2017). Manajemen Sumber Daya Manusia Profesional. Zifatama Publisher.

Nurhanispa, A. (2020). Pengaruh Kompensasi dan Disiplin Kerja Terhadap Kinerja Pegawai Honorer Dinas Bimatarung Provinsi Sulawesi Tengah.

Rivai. (2014). Manajemen Sumber Daya Manusia untuk Perusahaan (6th ed.). PT Raja Grafindo Persada.

Sihabudin. (2017). Positioning of Futsal Management Company: A Case Study. International Research Journal of Management, IT and Social Science, 4.

Sihabudin. (2018a). Influence of Teacher Training and Promotion on Teacher Performance to Subang Paddy Research Center. International Journal of Busisess, Economics and Management, 1, 6474 .

Sihabudin. (2018b). Peran Kepemimpinan dan Kompensasi Terhadap Kinerja Karyawan PT. Taiho Nusantara. 2Media Bina Ilmiah, 13, 1223-1230.

Sihabudin. (2019a). Pengaruh Marketing Public Relation dan Kualitas Pelayanan Terhadap Keputusan Berkunjung ke Wonderland Adventure Waterpark (PT. Galuh Citarum Karawang). Media Bina Ilmiah, 13, 1537-1548. 
Sihabudin. (2019b). The Importance of Providing Incentives and Motivation in Improving Teacher Performance. International Journal of Science and Society, 1, 91-97.

Sugiyono. (2017). Metode Penelitian Pendidikan Pendekatan Kuantitatif, Kualitatif, dan R\&D. Alfabeta.

Sungkono. (2016). Pengaruh Disiplin Dan Motivasi Terhadap Kinerja Pegawai Bidang Tata Ruang Dan Permukiman Pada Dinas Cipta Karyawa Kabupaten Karawang. Jurnal Manajemen Bisnis.

Sutrisno, E. (2016). Manajemen Sumber Daya Manusia. Prenada Media Group.

Wanta. (2017). Analisis Disiplin Kerja Terhadap Kinerja Pegawai Dinas Perikanan dan Kelautan Kabupaten Karawang. Jurnal Manajemen Bisnis.

Yani. (2012). Manajemen Sumber Daya Manusia. Mitra Wacana Media.

Yulandri, O. (2019). Pengaruh Kompensasi dan Disiplin Kerja Terhadap Kinerja Karyawan. Journal of Business, Management and Accounting . 